\title{
Biotic and Hydrologic Variables in Prairie Potholes in North Dakota ${ }^{1}$
}

\author{
CHARLES E. SLOAN
}

Hydrologist, U.S. Geological Survey, Denver, Colorado.

\section{Highlight}

Prairie potholes or sloughs are depressions of glacial origin that occur north of the Missouri River in the prairie region of the United States and Canada. Potholes provide valuable wetland habitat for migratory waterfowl and are widely used for stockwater supplies. Differences in climate, geology, topography, ground-water hy. drology, and land use create wide variations in pothole hydrology. Plants in and adjacent to potholes are useful indicators of water permanence, depth, and salinity-variables that are important in wetland management.

Prairie potholes or sloughs (Fig. 1) are water-holding depressions of glacial origin that occur in the prairies of the north-central United States and south-central Canada. Prairie potholes occur in greatest number and variety in hummocky knob-and-kettle topography (stagnation moraine) created by glacial stagnation. Potholes comprise one of the best wetland habitats for waterfowl breeding on the continent, and also provide forage and water supply for livestock use. Drainage of potholes for agricultural purposes has destroyed many valuable wetlands throughout the region and threatens a large share of the remainder.

\footnotetext{
${ }^{1}$ Publication authorized by the Director, U.S. Geological Survey. Received November 24, 1969; accepted for publication January 27, 1970.
}

\section{Hydrology}

The U.S. Geological Survey initiated a study of prairie-pothole hydrology in 1959 by using the mass-transfer method to evaluate evapotranspiration (Shjeflo, 1968). The initial study was followed by a study of ground-water flow systems and their effects on pothole hydrology (Sloan, 1967; Eisenlohr and Sloan, 1968). It was apparent throughout the prairie-pothole studies that wetland plants were adjusted to a hydrologic regimen, but until the general hydrology of the potholes was understood the value of pothole vegetation as hydrologic indicators could not be fully appreciated.

Water supply to prairie potholes results from precipitation directly on the pothole, surface flow from the pothole watershed, and seepage inflow of ground water. Snowmelt runoff in the spring and precipitation on the pothole surface are the largest sources of water. Mean annual precipitation in the vicinity of the potholes that were studied ranges from 15 to 19 inches, whereas average evapotranspiration ranges from 32 to 34 inches. Thus, there is a strong tendency for potholes to go dry unless water loss is compensated by surface and seepage inflow. Although seepage inflow to most potholes is small, it has a marked effect on water quality. All inflow processes carry dissolved solids into the pothole but in differing concentrations. Concentration of dissolved solids is extremely low in precipitation (less than $5 \mathrm{mg} /$ liter), moderately low in surface flow (less than 50 $\mathrm{mg} /$ liter), and relatively high in seepage inflow (more than $500 \mathrm{mg}$ / liter).

Water losses from potholes with emergent vegetation result from evapotranspiration, overflow and seepage outflow. Dissolved solids in the pothole water can be removed by overflow or seepage outflow, but cvapotranspiration removes water only as vapor and concentrates the dissolved solids. In the absence of overflow, outflow seepage is the only effective mechanism for removing the solids dissolved in the water. Thus, the relative salinity of water in potholes without overflow is a measure of net seepage, or the inflow-outflow balance. To a lesser extent, seepage influences permanence of water in a pothole by hastening or retarding the rate of water loss, depending upon the dominance of outflow or inflow scepage respectively. The seepage balance in the pothole is controlled primarily by the position of the adjacent water table rather than by the permeability of the bottom sediments. If the adjacent water table is higher than the pothole, there is seepage inflow and the water in the pothole is relatively permanent and salinity is generally greater than $15,000 \mathrm{mg} /$ liter of dissolved solids. If the adjacent water table is lower than the pothole, there is seepage outflow and the water is relatively temporary and dissolved solids are generally less than $500 \mathrm{mg} /$ liter. In most pot- 


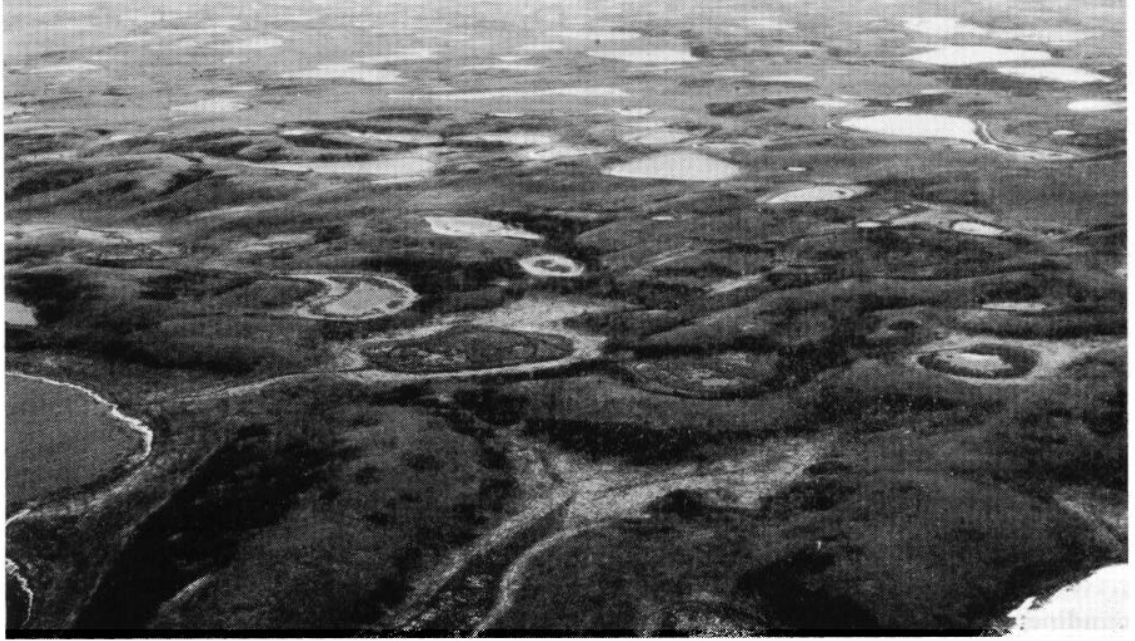

FIg. 1. Oblique aerial photograph of prairie potholes in Stutsman Co., from an altitude of about 1,000 feet, showing hummocky knob-and-kettle topography characteristic of stagnation moraine.

holes the adjacent water table is higher than the water surface in the pothole on one side and lower on the other creating simultaneous seepage inflow and outflow called throughflow. These potholes are intermediate in permanence and salinity.

Table 1 summarizes the more common constituents that are dissolved in prairie pothole waters. The predominant salt in fresh potholes is calcium bicarbonate (Ca $\left.\left(\mathrm{HCO}_{3}\right)_{2}\right)$. Magnesium sulfate $(\mathrm{Mg}$ $\mathrm{SO}_{4}$ ) predominates in brackish potholes, whereas sodium sulfate $\left(\mathrm{Na}_{2}\right.$ $\mathrm{SO}_{4}$ ) is the primary constituent in saline potholes.

Differences in climate, geology, ground-water conditions, topography, land use, and other factors

create wide differences in the hydrologic regimen of potholes. Permanence of water in the potholes ranges from only a few days after spring snowmelt to more or less permanent ponds. Salinity of water in potholes ranges from very fresh to brines that are several times more concentrated than sea water. Pothole size ranges from a small fraction of an acre to several square miles although potholes larger than about 40 acres are usually called lakes. Most prairie potholes are shallow, seldom exceeding 4 or 5 feet in depth and usually are less than 2 or 3 feet deep. Salinity and depth of water can fluctuate rapidly within an individual pothole both seasonally and annually in response to inflow and outflow.

Table 1. Chemical analysis of (1) fresh, (2) brackish, and (3) saline pothole waters showing the main cations, anions, and dissolved solids. (Concentrations of dissolved constituents and dissolved solids given in $\mathrm{mg} /$ liter.)

\begin{tabular}{lrrrrrrrrr}
\hline \hline $\begin{array}{c}\text { Pothole } \\
\text { water }\end{array}$ & Calcium & $\begin{array}{c}\text { Mag- } \\
\text { nesium }\end{array}$ & Sodium & $\begin{array}{c}\text { Potas- } \\
\text { sium }\end{array}$ & $\begin{array}{c}\text { Bicar- } \\
\text { bonate }\end{array}$ & Sulphate & Chloride & $\begin{array}{c}\text { Calculated } \\
\text { dissolved } \\
\text { solids }\end{array}$ \\
\hline Fresh & 34 & 12 & 2.8 & 24 & 144 & 31 & 6.9 & 254 \\
Brackish & 250 & 534 & 470 & 85 & 473 & 3,260 & 71 & 5,450 \\
Saline & 729 & 2,700 & 4,540 & 510 & 355 & 17,910 & 2,590 & 29,200 \\
\hline
\end{tabular}




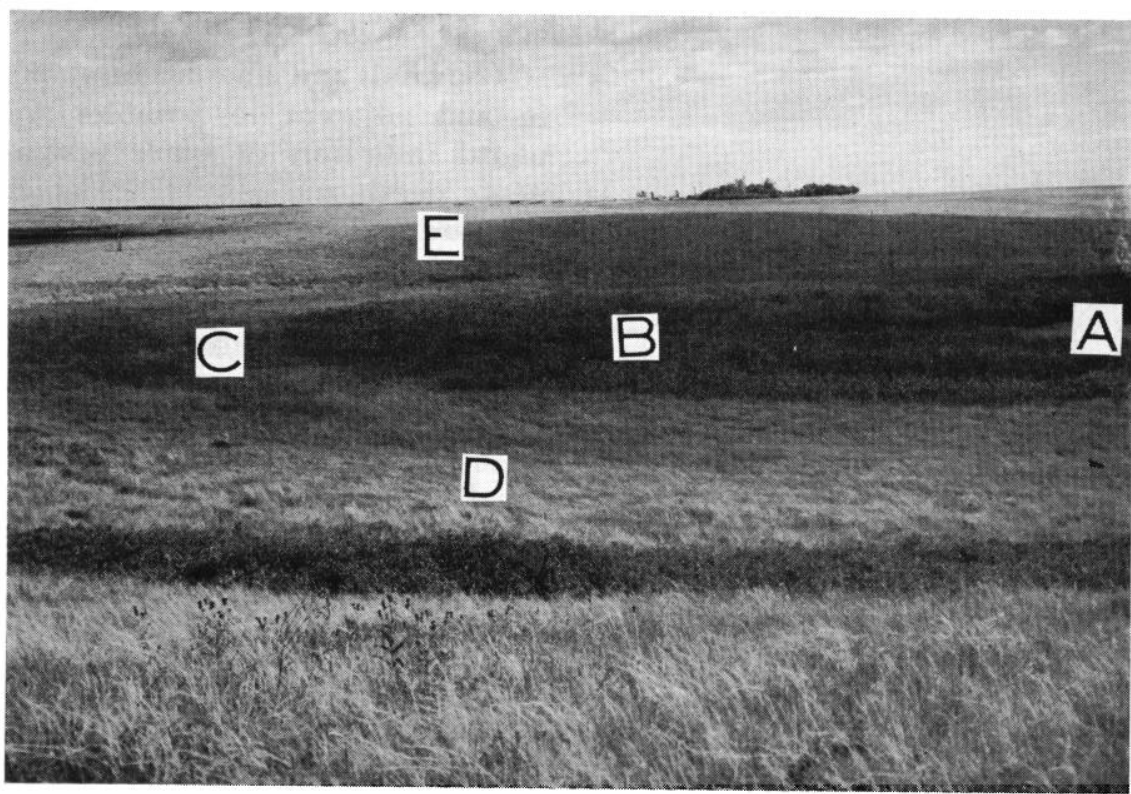

FIG. 2. Deep-marsh zone (B) in a slightly-brackish pothole contains mixture of cattail and hardstem bulrush, 3 to 5 feet tall, surrounding an open-water zone (A). Shallowmarch (C) and wet-meadow (D) zones form concentric peripheral bands of vegetation between the deep-marsh zone and the low prairie grasses (E) on the uplands.

zones, occur where water is maintained throughout summer and frequently into fall and winter. Emergent plants in the deep-marsh zone commonly include cattails (Typha sp.), hardstem bulrush (Scirpus acutus), river bulrush (Scirpus fluviatalis), and alkali bulrush (Scirpus paludosus). In potholes having more than one zone, the central deeper part usually constitutes one zone while the other zones form concentric peripheral bands around it (Fig. 2).

The distribution of emergent plant cover is related to the depth of water. Continuous or closed stands of emergent plants occur in comparatively shallow water. Peripheral stands surrounding an open expanse of water indicate deep-water conditions. Isolated stands of emergent plants interspersed with open water are characteristic of intermediate depth.

The species composition of wetland vegetation is closely related to relative salinity. A few plant species, including giant burreed, broadleaf water-plantain (Alisma triviale), slender bulrush (Scirpus heterochaetus), and variable leaf pondweed (Potamogeton gramtheir best development under these hardstem bulrush in grazed part on right. intermediate conditions. A limited number of salt tolerant plants including alkali grass (Puccinellia nuttalliana), samphire (Salicornia rubra), alkali bulrush, and widgeon grass (Ruppia maritima), occur commonly in saline potholes.

The predominance of certain emergent species in the deep-marsh zone is related to relative salinity, as indicated in Table 2.

Some difference in species composition of the dominant emergent plants is due to the effect of land use (Fig. 3). In slightly brackish potholes where shallow-marsh plants occupy the central deeper part, slough sedge and whitetop are codominant under non-use conditions; whitetop is dominant in mowed potholes, slough sedge is dominant in lightly grazed potholes; common spikerush is dominant in heavily grazed potholes; and sloughgrass is dominant in potholes that are in an early successional stage from prior cultivation.

\section{Conclusions}

Prairie potholes occupy a dynamic hydrologic environment characterized by wide spatial and temporal variations. Much of the hydrologic variability is influenced

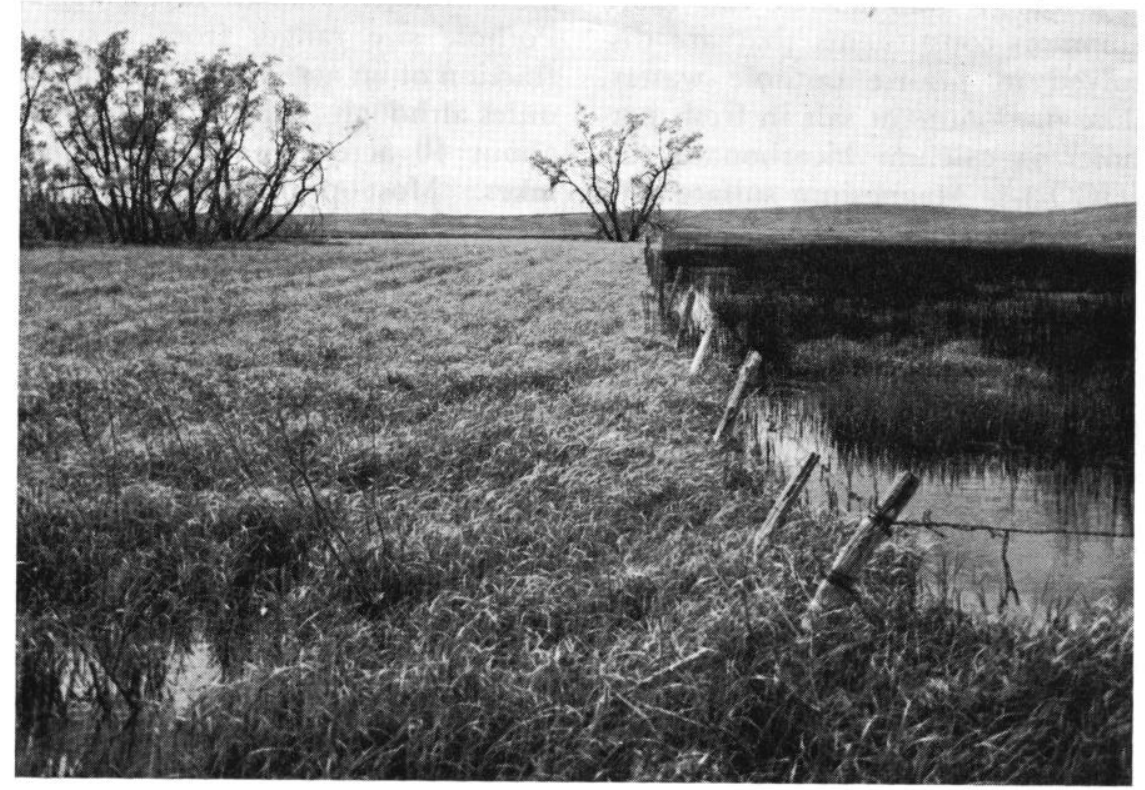

FIG. 3. Land-use effects on species composition is shown by the dominance of whitetop in the previously mowed part of the pothole to left of fence and by dominance of 
Table 2. Relationship of relative salinity (mg dissolved solids/liter) to predominance of emergent species in the deep-marsh zone.

\begin{tabular}{|c|c|c|}
\hline Relative salinity & Approx. range & $\begin{array}{l}\text { Dominant plant } \\
\text { associations }\end{array}$ \\
\hline Fresh & 500 & Slender and/or river bulrush \\
\hline Slightly brackish & $200-1,500$ & $\begin{array}{l}\text { Cattail, or mixtures of cattail } \\
\text { and hardstem bulrush }\end{array}$ \\
\hline Moderately brackish & $750-6,000$ & Hardstem bulrush \\
\hline Brackish & $1,000-15,000$ & $\begin{array}{l}\text { Mixtures of hardstem and } \\
\text { alkali bulrush }\end{array}$ \\
\hline Saline & $3,000-35,000+$ & Alkali bulrush \\
\hline
\end{tabular}

by the characteristics of the groundwater flow system at the pothole. Wetland plants are useful indicators of pothole hydrology because they tend to smooth out short term hydrologic variations and represent a longer term integrated water balance for the potholes.

\section{Literature Cited}

Eisenlohr, W. S., JR., AND C. E. SLOAN. 1968. Generalized hydrology of prairie potholes on the Coteau du Mis- souri, North Dakota. U.S. Geol. Survey Circ. 558, 12 p.

ShJEFLo, J. B. 1968 . Evapotranspiration and the watcr budget of prairie potholes in North Dakota. U.S. Geol. Survey Prof. Paper 585-B, 49 p. SLOAN, C. E. 1967. Ground-water movement as indicated by plants in the prairie pothole region. In I.ee Clayton and Theodore F. Freers, eds., Glacial geology of the Missouri Coteau, N. Dak. Geol. Survey Misc. Series 30:95-99.

Stewart, R. E., and H. A. Kantrud. 1969. Proposed Classification of potholes in the glaciated prairie region, in small water areas in the prairie pothole region-Transactions of a seminar. Canadian Wildlife Serv. Report. Ser. 6:57-69. 